\title{
The Use of Social Media for New College Student Development Process
}

\author{
Alam Asrorul Haq ${ }^{\mathrm{a}, 1, *}$, Aris Maulana ${ }^{\mathrm{a}, 2}$, Dimas Ramadhan ${ }^{\mathrm{a}, 3}$, Dyanrosa Debora ${ }^{\mathrm{a}, 4}$, Prananda \\ Anugrah $^{\mathrm{b}, 5}$ \\ ${ }^{a}$ Department of Electrical Engineering, Universitas Negeri Malang, Malang,Indonesia \\ ${ }^{\mathrm{b}}$ Association for Scientific Computing Electrical and Engineering, Yogyakarta, Indonesia \\ 1 alamasrorulhaqraccer@gmail.com; ${ }^{2}$ maulanaaris221@ gmail.com; ${ }^{3}$ dr081dimas@ gmail.com; ${ }^{4}$ dyanrosa.deb@ gmail.com; \\ ${ }^{5}$ prananda.anugrah@gmail.com
}

\begin{tabular}{|c|c|}
\hline Article Info & ABSTRACT \\
\hline $\begin{array}{l}\text { Article history: } \\
\text { Received: July 17, } 2018 \\
\text { Revised: August 20, } 2018 \\
\text { Accepted: August 30, } 2018\end{array}$ & $\begin{array}{l}\text { This study was conducted to examine how the use of social media to developing a new } \\
\text { college student at State University of Malang. This study uses in-depth interviews } \\
\text { method were conducted in a manner that has been structured. This method applied to } \\
\text { eight new college students to get information from students about the new college } \\
\text { student development through social media. All the students in this case, uses social } \\
\text { media Whatsapp and Instagram in their development process, only a few students who } \\
\text { use LINE and Facebook. This study focuses on three things that is how social media is } \\
\text { used to perform a new student development, student response in development through } \\
\text { social media and the tendency of students to choose development process through } \\
\text { social media or directly development process. The results of this study can be obtained } \\
\text { that social media help in the process but the given information must be complete and } \\
\text { clear. }\end{array}$ \\
\hline
\end{tabular}

\section{INTRODUCTION}

Social media is an online community that was established with the aim of facilitating communication and exchange of information [1]. The age range of social media users is between $15-75$ years [2]. In a survey conducted by Shabnoor Siddiqui and Tajinder Singh from Mats University says that $90 \%$ of the students using social media [3]. The use of social media in education especially among the students, that is social media can facilitates the exchange of information between students in development. In a study conducted by Owusu-Achean and Agatha Gifty from University Of Education mention of 1578 questionnaires were distributed, the students usually spend 30 minutes until 3 hours to open social media every day [4]. Social networking / social media has a significant impact on individuals, especially students [5]. With social media, students can easily obtain information without meeting people face to face. This way can increase the efficiency of time and energy, that students do not bother in the search for information. However, social media has some good and bad impact for user and the social environment [6].

The advantages of social media that is safe and direct messages from the sender to the recipients with a relatively very quickly thereby increasing the efficiency of time for users [3]. Social media also has some disadvantages and misused function, for example it can be used to slander or abuse others [7]. Many cases by using fake accounts, people can disguised or use other name to do things they want to.

Development by do an action through the process will give a better result. There are many kind of developing process such as establish manners, morals, discipline, and others. Developing has two types that is direct and indirect. Direct development is a process of giving information from one person to another without going through a third person or a media. Indirect development is a process of giving information through a media as an intermediary. Development of new college students in this study is a lecture related information, order and discipline in the college life. In the process of achieving the quality of human resources in college, much needed synergy between academic work with students in the field of development [8]. Guidance also has an important role in improving the quality of campus [9]. With the development of the academic field, students can be more orderly and directed so that the campus has a better graduated. 
In the previous research, studying about how a new college student in Japan finding a friend then interacted with them using social media. This research using in-depth interview to gain information to 8 new college students and use social media Line because almost all new students use Line. The result of the research show how Japanesse students interactions with their friends through social media. Like how they use social media, what their action after read a message, and what their interaction in a Line group they in [10].

\section{METHOD}

TABLE I. INTERVIEWEES DATA

\begin{tabular}{|c|c|c|c|c|}
\hline & Gender & Study Program & $\begin{array}{c}\text { Social Media } \\
\text { Used } \\
\end{array}$ & $\begin{array}{c}\text { Date } \\
\text { Interviewed }\end{array}$ \\
\hline A & Man & $\begin{array}{l}\text { Informatics } \\
\text { Engineering }\end{array}$ & $\begin{array}{l}\text { Whatsapp, } \\
\text { Instagram, } \\
\text { Facebook }\end{array}$ & October 3rd, 2018 \\
\hline B & Woman & $\begin{array}{l}\text { Informatics } \\
\text { Engineering }\end{array}$ & $\begin{array}{l}\text { Whatsapp, } \\
\text { Instagram }\end{array}$ & October 3rd, 2018 \\
\hline $\mathrm{C}$ & Man & $\begin{array}{l}\text { Mechanical } \\
\text { Engineering }\end{array}$ & $\begin{array}{l}\text { Whatsapp, } \\
\text { Instagram, } \\
\text { Line }\end{array}$ & October 8th, 2018 \\
\hline D & Woman & $\begin{array}{l}\text { Informatics } \\
\text { Engineering }\end{array}$ & $\begin{array}{l}\text { Whatsapp, } \\
\text { Instagram }\end{array}$ & October 8th, 2018 \\
\hline $\mathrm{E}$ & Woman & $\begin{array}{l}\text { Educational } \\
\text { Informatics } \\
\text { Engineering }\end{array}$ & $\begin{array}{l}\text { Whatsapp, } \\
\text { Instagram }\end{array}$ & 14 November 2018 \\
\hline F & Man & $\begin{array}{l}\text { Educational } \\
\text { Informatics } \\
\text { Engineering }\end{array}$ & $\begin{array}{l}\text { Whatsapp, } \\
\text { Instagram, } \\
\text { Facebook }\end{array}$ & 14 November 2018 \\
\hline G & Man & $\begin{array}{l}\text { Industrial } \\
\text { Engineering }\end{array}$ & Whatsapp & 14 November 2018 \\
\hline $\mathrm{H}$ & Woman & $\begin{array}{l}\text { Informatics } \\
\text { Engineering }\end{array}$ & $\begin{array}{l}\text { Whatsapp, } \\
\text { Instagram, } \\
\text { Facebook, } \\
\text { Line }\end{array}$ & 14 November 2018 \\
\hline
\end{tabular}

This study uses in-depth interviews method. In-Depth interviews are face-to-face meeting between researchers and informants are being made to obtain information about a resource perspective to the research topic [11], [12]. In a process of in-depth interviews, there are several steps that is arrange questions, interviews, discussions and conclusions [13]. The first thing to do in this research is to make inquiries. Create questions used to obtain the data, the data will be used for discussions in making conclusions from this study. The data that used in this research as follows:

- Name, ID, study program and hometown of interviewees.

- Social media used by interviewees.

- Social media used in development process.

- Characteristics of guidance obtained by the interviewees.

- Development process types like direct or indirect.

- The effective of development process types in direct way or through social media.
- Comparison of development process types by interviewees.

- Another detailed information about development process

In the process of finding a interviewees, interviewees should are a new college students from the Faculty of Engineering, State University of Malang. In this study, a total of interviewees as many as eight student that consists of four men and four women. Students are interviewed around the engineering faculty area. With their approval, every interview are recorded by sound recorder. The results of the interview then collected and used as a discussion. Data of interviewees as in the Table 1 .

\section{RESULT AND DISCUSSION}

Students who are used as sources, are users of social media and receive a development through social media. There are three important points which is the focus of this research. First, how social media is used to conduct training of new students. Second, the student action in response to development through social media. The third, tendency of respondents to choose between social media or directly development process.

\section{A. Uses of Social Media for Development Process}

The entire students in this research revealed that they ever received development or guidance through social media. When asked about what social media is used, all off students answered Whatsapp and Instagram. Only few students still using Line or Facebook, but when asked about social media is often used as a development process, students A to G said that they use Whatsapp application. While student $\mathrm{H}$ says that her often received a guidance as development via Instagram.

According to student $\mathrm{H}$, development on Instagram are done by giving a poster or infographic about a guidance, and provided detailed information through the caption. This is because Instagram is a photo sharing service or video [14], and can be given caption therein. Guidance is given by an official account that is managed by the admin. While a whole students said that they obtain guidance through the relevant groups such as faculty group, department, or class in Whatsapp. The majority of students also choose Whatsapp for the group feature that can facilitate the discussion with [15]. According to students, within the group have one or two representatives of the Student Association who is students that elder than them or a lecturer. Each representative provides information on developing via the group chat, in other hands, this ways is to prevent hoax news in a groups.

When asked how the characteristic of development process, students $\mathrm{B}, \mathrm{C}$, and $\mathrm{D}$ said that a development process are assertive and coercive. Almost half of students said, that characteristic in the social media shown such as emphasis or bold on a specific text.

\section{B. Responses in the Development Using Social Media}

Students responses in given information as development process through social media when they felt confused or 
misunderstanding is diverse and some are different from the other. Students A, E, F, and $\mathrm{H}$ prefer to ask directly in a group when information given through social media group because it is easier. But student $\mathrm{E}, \mathrm{F}$ and $\mathrm{G}$ said that they would ask them in personal chat directly through to the giver information. In development process, almost all of students prefer ask directly in a message to information giver, while students B and C prefer to ask another friend because they feel embarrassed and ashamed. But student $\mathrm{C}$, did not feel shy or embarrassed to ask the lecturer. Some of students will be asking friends, but if their friends also do not understand, they will inquire directly message through the personal chat feature.

Besides of responses when students not understanding a content of information, responses when students understanding also been studied. All respondents prefer not reply anything or just to read it after information given. According to one student, there are many students who responded within the group. But the answer of those responses are long enough. An study said, that read-only activity in a chat room can disrupt the formation of learning communities and compromise [16].

\section{The Tendency to Choose Development through Social Media and Direct}

When asked about what they choose between developing through social media or directly which is face-to-face, a majority of students, choose direct types. The only one who choose through social media is student A, because it is easy to do. In addition to guidance through chat have tangible proof, so when he forget then want to know about the information again, he will be able to look back on the chats. But students $\mathrm{B}, \mathrm{C}, \mathrm{D}, \mathrm{F}, \mathrm{G}$, and $\mathrm{H}$ have some own reasons for choosing directly development. Students B, C, D, G, and $\mathrm{H}$ feels that directly is clearer than through social media and they able to ask directly. Student F also choose directly because through social media is not very effective. According to the student F, there are some students who live in a boarding school, not be allowed to carry a smartphone or if they do, their smartphone will be confiscated by the boarding school so they didn't get information in development process. The same thing can be told by students D. Students E prefer both, because when through social media she felts simple, but the response in reply to the giver feels late.

Although most students chose development in directly, when asked whether social media helps in development process, all students agree with that. The reasons of students who choose directly, because there is some lack of development process in social media. According to the student $\mathrm{E}$, one of the shortcomings of development through social media is the length-time of the response of the giver coaching. Meanwhile, according to $\mathrm{G}$, development is less clear because it only contains a text. According to $\mathrm{C}$ and $\mathrm{D}$, because not all students are able to use social media continuously as a student who lives in a boarding school.

\section{CONCLUSION}

The interview results, revealed that social media help in providing guidance to new students, but information must be complete and clear. Basically development through social media is efficient enough to provide guidance because information can be given at any time. However, not all students feel like it, because development on social media is not too clear that students can felt confused also embarrassed to ask and in the end, they choose to ask the friend known. In addition to external factors such as duration of response giving guidance on social media and the inability of students to use smartphones for some reason can hinder the process of development through social media. From the students themselves, read-only responses in a chat room can disrupt the formation of communities and learning to compromise. All of students agreed that social media helps in the development process of new students, with a complete and clear information.

\section{References}

[1] M. N. Hajli, "A study of the impact of social media on consumers," Int. J. Mark. Res., vol. 56, no. 3, pp. 387-404, May 2014

[2] P. B. Brandtzæg, "Social networking sites: Their users and socia implications - A longitudinal study," J. Comput. Commun., vol. 17, no. 4, pp. 467-488, 2012.

[3] S. Siddiqui and T. Singh, "Social Media its Impact with Positive and Negative Aspects," Int. J. Comput. Appl. Technol. Res., vol. 5, no. 2, pp. 71-75, 2016.

[4] M. Owusu-Acheaw and A. G. Larson, "Use of Social Media and its Impact on Academic Performance of Tertiary Institution Students: A Study of Students of Koforidua Polutechnic, Ghana," J. Educ. Pract., vol. 6, no. 6, pp. 94-101, 2015.

[5] F. Farooq and Z. Jan, "The Impact of Social Networking to Influence Marketing through Product Reviews," Int. J. Inf. Commun. Technol. Res. , vol. 2, no. 8, pp. 627-637, 2012.

[6] M. Sponcil and P. Gitimu, "Use of social media by college students Relationship to communication and self-concept," J. Technol. Res., vol. 4, pp. 1-14, 2013.

[7] J. Amedie, "Impact of Social Media on Society," St. Cl. Univ. Sch Commons, no. December, pp. 48-49, 2012.

[8] Sumaryanto, "Pola Pengembangan Pembinaan Kegiatan Kemahasiswaan," in Diskusi Pendidikan BEM FIP UNY, 2012.

[9] F. L. Kambey and S. Suharnomo, "Pengaruh Pembinaan, Pelatihan Dan Pengembangan, Pemberdayaan Dan Partisipasi Terhadap Kinerja Karyawan,” J. Stud. Manaj. Organ., vol. 10, no. 2, pp. 142-151, 2013.

[10] S.-M. Kim, "Exploratory Research on Social Media and Digital Writing: Qualitative Interview of Japanese College Students," J. SocioInformatics, vol. 8, no. 1, pp. 13-27, 2016.

[11] C. MacDougall and E. Fudge, "Planning and recruiting the sample for focus groups and in-depth interviews," Qual. Health Res., vol. 11, no. 1, pp. 117-126, 2001.

[12] Z. R. Milena, G. Dainora, and S. Alin, "Qualitative Research Methods: A Comparison Between Focus-Group And In-Depth Interview," Ann. Univ. Oradea, Econ. Sci. Ser., vol. 17, no. 4, pp. 1279-1283, 2008.

[13] C. Boyce and P. Neale, "Conducting In-Depth Interviews: A Guide for Designing and Conducting In-Depth Interviews for Evaluation Input," Pathfind. Int. Tool Ser. Monit. Eval. - 2, 2006.

[14] Y. Hu, L. Manikonda, and S. Kambhampati, "What We Instagram: A First Analysis of Instagram Photo Content and User Types," Proc. ICWSM. AAAI., p. 4, 2014. 
[15] M. N. Kamel Boulos, D. M. Giustini, and S. Wheeler, "Instagram and WhatsApp in health and healthcare: An overview," Futur. Internet, vol. 8, no. 3, p. 37, 2016.

[16] L. Nagel, A. S. Blignaut, and J. C. Cronjé, "Read-only participants : a case for student communication in online classes," Interact. Learn. Environ., vol. 17, no. 1, pp. 37-51, 2009. 